\title{
MODELING OF AN OBSERVATION CHECKLIST OF
} MOTOR BEHAVIOR

\author{
Jūratė Požèrienė, Diana Rèklaitienė, Danguolẻ Venslavičè \\ Lithuanian Academy of Physical Education, Kaunas, Lithuania
}

\begin{abstract}
Research background and hypothesis. The study started with the hypothesis that direct observation of a child could be used as part of assessment of various internal problems. The results of recent observational studies on depressed children show that explicit behavioral symptoms of depression, such as psychomotor agitation, can be systematically observed during standardized procedures.

Research aim. The aim of the study was to construct a checklist of motor behavior for children aged 11-12 years with internal problems.

Research methods. Items for the checklist were recorded from DSM-IV and ISD-100. Children of 11-12 years $(\mathrm{n}=75)$ were videotaped whilst participating in physical education lessons. Achenbach's Child Behavior Checklist (Youth Self-Report for Ages 11-18 (YSR) and Teachers' Report Form for Ages 5-18 (TRF)) were applied to the sample as well. The results from YRS and TRF were used for the development of validity statistics. Reliability statistics was calculated as well.

Research results. The 14 statements were selected for the development of observation of motor behavior for children with internal problems. Result showed that the internal consistency (Cronbach's $\alpha=0.79$ ) and reliability $(I C C=0.81)$ of the checklist were good. The insignificant result of dispersion among the observer group $(\mathrm{F}=7.233$, $(\mathrm{df}=4) \mathrm{p}=0.423)$ showed that the observers agreed when assessing children.

Discussion and conclusions. The instrument will be useful in screening children with possible internal problems and assisting in intervention planning aimed at influencing motor behavior. The study has a number of limitations the sample is too small, the more extensive check of validity and reliability is required.
\end{abstract}

Keywords: observation, internal problems, protocol of motor behavior, validity, reliability.

\section{INTRODUCTION}

$\mathrm{M}$ otor development may be defined as the change of motor behavior during life due to various processes that determine this change. A child's motor development is closely related to the child's psychosocial development that encompasses emotions, personality, and interrelations with other people that surround him/her. Consequently all people express their personalities as they move, ant motor behavior may be corrected seeking for an advantage for the whole personality. Evaluation of children's motor behavior differs from physiological measurements, physical capability tests, and even from children's motor development tests, assessed with the help of quantitative values. J. D. Cone (1978) grouped the assessment of motor behavior into two categories: 1) direct assessment defined by observation in natural children's environment or in situations, analogous to natural environments, and selfobservation; and 2) indirect assessment defined by various surveys, reports, and questionnaires. Many scientists (Mol Lous et al., 2002; Fortes et al., 2005; Thomas, Nelson, 2005; Causgrove Dunn, Dunn, 2006) state that direct assessment methods are most suitable in research that studies children with emotional and behavior disorders.

Self-reports, reports, questionnaires and checklists are created for the assessment of depression, anxiety, and other internal problems. However, all assessment methods have drawbacks. 
For this reason and because anxiety and depression are not tangible assessment objects, many scientists (Puura et al., 1998; Seligman, Ollendick, 1998; Saleem, Mehmood, 2011) came to the conclusion that internal disorders should be identified using as many different assessment methods as possible. Short and quickly filled reports or questionnaires may just repeat each other, while, when filling in self-reports, children may be dishonest and may give those answers, which are supposed to be socially acceptable (Thomas, Nelson, 2005). It is also important to collect information from different informants because parents, teachers, and other specialists (social workers, medical professionals, specialists of adapted physical activity, etc.) observe children's behavior in different contexts, and their answers usually do not correlate well among themselves (Puura et al., 1998; Pool, Hourcade, 2011). Therefore various assessment methods, which would be applied in different environments and by which it would be possible to gather information from different sources, must be researched more exhaustively and should be used more often in scientific research and practice. Motor behavior is not usually included or is not emphasized in many currently known self-reports, reports, questionnaires, and checklists for the assessment of internal problems. Results of several last scientific papers (Mol Lous et al., 2002; Pool, Hourcade, 2011), where the direct observation method was used, showed that psychomotor excitement or suppression might be observed systematically in standardized game situations. When analyzing observation checklists, J. R. Thomas and J. R. Nelson (2005) noticed that children behaved more casually and more naturally in natural environments (such as a playground or a class) than at a specialist's, behind the closed door. We used these assumptions to develop our hypothesis that direct observation of motor behavior in a natural environment may be used as one of the methods for identification and assessment of various internal problems. Research aim was to create a motor behavior observation checklist for children aged 11-12 with internal problems.

\section{RESEARCH METHODS}

The subjects. We used convenience and systematic sampling. First, we selected the secondary school, where administration and physical education teacher agreed to participate in the study; and second, the subjects had to be 11-12 years old. The study included 75 students from secondary schools: 41 of them were boys (aged $11.95 \pm 0.31$ ) and 34 were girls (aged $11.86 \pm 0.42$ ).

Research methods: 1) coding of motor behavior - diagnostic criteria of various anxiety and mood disorders described in diagnostic classifications, were used for the creation of a specific motor behavior list that reflected internal problems: DSM-IV (Diagnostic and Statistical Manual of Mental Disorders, $4^{\text {th }}$ edition, American Psychiatric Association, 1994) and ICD-10 (The ICD-10 Classification of Mental and Behavioral Disorders: Diagnostic Criteria for Research, World Health Organization, 1993); 2) observation; 3) videotaping; 4) Teacher's Report Form and Youth Self Report Form (Achenbach, 1991) for 11-18-yearold youths. Eight syndromes were distinguished in the reports, and they were divided into internal and external problems. These reports are valid and reliable for the population of Lithuanian children (Žukauskienè et al., 2003).

Statistical analysis was performed using Statistical Package for Social Sciences (SPSS) version 11.0. Averages of values of selected statements for the future checklist and correlation of each statement with the item to total correlation were calculated. Reliability, the internal consistency of the checklist, based on Cronbach's $\alpha$, and concurrence of opinions between separate observers, using the ICC (intraclass correlation coefficient), were calculated. When assessing validity, the Pearson's correlation coefficient between the sum of values of the new checklist and the subscales of internal and external problems of the 11-18-year-old Youth Self Report Form, and between the new checklist and internal and external subscales of the Teacher's Report Form was calculated.

Organization of research. The coding of statements that define motor behavior was done by a group of three experts (specialists of adapted physical activity and psychomotor functions, and a psychologist). Another group of experts that assessed all statements was chosen based on the following criteria: higher education, experience of at least two years of working with children, a possibility to observe children in movement situations, possession of practical and theoretical knowledge related to behavioral disorders and motor development, and motivation to participate in the research. Independent specialists of various areas of the second expert group (one specialist of adapted physical activity, two special pedagogues 
and two qualified doctors in psychotherapy psychology, one coach, one game specialist, one physiotherapist, and two social workers) assessed each statement, and a motor behavior observation checklist was composed. The research objects $(n=75)$ were filmed in class after receiving the permission of school administration, the teacher of physical education, and the children's parents. Seeking to decrease the filming effect that might change the behavior of the ones being filmed (Thomas, Nelson, 2005); the teacher was asked not to change the usual course of the lesson. It was explained that the lesson itself would not be assessed, and that it was important for the researchers to record moving children. The material, used in the research, was filmed during repeated filming, with the assumption that an already familiar process of filming during the lesson once again would distract children less. Numbers were tagged to children's shirts according to their list in the school journal. The children's names and surnames were not used anywhere in the research seeking to ensure their anonymity. On the same day of the filming the Teacher's Report Form was distributed to teachers, and the 11-18-year-old Youth Self Report was distributed to the same set of children. The physical education teacher was asked to observe the same researched children and to assess them using the newly composed observation checklist. The teacher observed the children during four lessons. The tape with the children participating in a physical education lesson was watched by six groups of students, consisting of three persons in each. The students were not specially instructed; they were only informed shortly about emotional and behavioral, especially internal, problems and their outcomes. Students observed 12 randomly chosen children (four out of each class), and they filled in the checklist after 10 minutes of observation.

\section{RESEARCH RESULTS}

A group of three experts, using diagnostic systems DSM-IV (1994) and ICD-10 (1993), selected 68 statements that defined motor behavior of children with internal problems. These statements were evaluated by eight qualified specialists ( $2^{\text {nd }}$ group of experts) with the help of a 5-point system: 1 - don't agree, 2 - slightly agree, 3 - don't know, 4 - partly agree, 5 - fully agree. During the selection of statements for the final checklist, attention was given to: 1) statements, which were assessed by experts as the most noticeable in a movement situation, were left; their value average ranged from 3.75 to 5 (51 statements were left in the scale); 2) seeking to avoid statements assessed in a contradictory way by the experts, all statements, the item to total correlation of which was less than 0.40 , were removed (26 statements were left); 3 ) in the last step each statement was analyzed separately, going back to diagnostic criteria, using thinking and not relying blindly on mathematical analysis (for example, both statements "a child is acting in an unorganized way" and "a child is moving as if aimlessly" described motor behavior which corresponded to the diagnostic criteria "unorganized behavior"; having decided that the statement "a child moves aimlessly" reflected the observed motor behavior better, the latter statement was left in the final list of statements). A list of 14 statements which were presented in the observation checklist was composed. The observation checklist form was chosen based on B. Lowenthal's (2001) suggestions. A decision was made to present basic information about the observer, the observed subjects, and explanatory information in the observation checklist. For the assessment of certain behavior, the 5-point Likert scale was chosen. The second expert group recommended defining assessment in such a way that after summing up the values undisturbed behavior would receive the smallest result, and the final result of the composed observation checklist would be the sum of assessment of all statements.

Motor behavior of almost all research participants was similar, and they did not have internal problems. Values of observation by the physical education teacher of all researched children were used to identify internal consistency of the checklist (see Table 1).

The result showed that the internal consistency of the checklist was good (Cronbach's $\alpha=0.79$ ). The concurrence of opinions of separate observers is very important for the confirmation of the reliability of the checklist, for the identification of which the ICC (intraclass correlation coefficient) was chosen; and the ICC reflects the concurrence of opinions of separate observers when assessing the same research subject, as well as the consistency of the opinion of a certain observer when assessing all research subjects (the observed). Children's observation values of six student groups were used for the calculation of the ICC, which reflected average correlation among observers. Therefore before the calculation of the intraclass correlation 
Table 1. The internal consistency of the checklist

\begin{tabular}{|l|c|c|c|c|}
\hline \multicolumn{1}{|c|}{ Statements } & $\begin{array}{c}\text { Scale } \\
\text { mean }\end{array}$ & $\begin{array}{c}\text { Scale } \\
\text { variance }\end{array}$ & $\begin{array}{c}\text { Corrected } \\
\text { item }\end{array}$ & $\begin{array}{c}\text { Cronbach's } \\
\text { Alpha }\end{array}$ \\
\hline The child looks sad (unhappy) & 19.613 & 34.943 & 0.3299 & 0.7857 \\
\hline The child is pulling his/her clothes & 19.613 & 38.592 & -0.0962 & 0.8093 \\
\hline The child looks distracted & 19.213 & 34.305 & 0.1869 & 0.8073 \\
\hline The child is unsubmissive & 19.133 & 33.279 & 0.3390 & 0.7873 \\
\hline The child prefers individual tasks & 19.253 & 30.678 & 0.7214 & 0.7521 \\
\hline $\begin{array}{l}\text { The child is frequently trying sit on a } \\
\text { bench or somewhere else }\end{array}$ & 19.613 & 35.835 & 0.3456 & 0.7858 \\
\hline The child's movements are constricted & 19.5733 & 35.0132 & 0.3959 & 0.7821 \\
\hline The child moves like without a goal & 19.560 & 35.196 & 0.3684 & 0.7836 \\
\hline The child demonstrates turns of anger & 19.453 & 34.549 & 0.4384 & 0.7791 \\
\hline $\begin{array}{l}\text { The child "stuck“ to the teacher or } \\
\text { another adult }\end{array}$ & 19.493 & 35.524 & 0.2715 & 0.7896 \\
\hline $\begin{array}{l}\text { The child's movements are unusually } \\
\text { slow }\end{array}$ & 18.933 & 29.279 & 0.5983 & 0.7601 \\
\hline $\begin{array}{l}\text { The child begins to move only } \\
\text { encouraged by an adult }\end{array}$ & 19.253 & 31.976 & 0.4739 & 0.7738 \\
\hline $\begin{array}{l}\text { The child is completely indifferent to } \\
\text { the achievements and failures }\end{array}$ & 19.253 & 30.678 & 0.6371 & 0.7579 \\
\hline $\begin{array}{l}\text { The child does not interact with other } \\
\text { children }\end{array}$ & 19.133 & 29.063 & 0.7509 & 0.7444 \\
\hline
\end{tabular}

coefficient, Pearson's correlation among all observers' groups was assessed.

Since the third group's assessment did not concur at all with the assessment of the fourth, fifth and sixth groups (Table 2), this group was removed from further reliability analysis. A two way random effect model (absolute agreement) was used to calculate the intraclass correlation coefficient (ICC). This model is most often used to check reliability when there is a need to define if the instrument is also suitable for other persons who have similar characteristics, and when there is no interaction between the observed and the observers. Based on the value of the intraclass coefficient ( $\mathrm{ICC}=0.81$ ) it is possible to state that the reliability of the new checklist was good. The insignificant result of dispersion among the observer group $(\mathrm{F}=7.233$, $(\mathrm{df}=4) \mathrm{p}=0.423)$ shows that the observers agreed when assessing children. The dispersion of values of the observed children around the average did not influence the size of the intraclass correlation coefficient, and the children's sample was sufficiently heterogeneous.

The content of the observation checklist concurred with DSM-IV and ICD-10 categories, intended to diagnose anxiety, depression, and social phobia. This confirmed the validity of the contents of the new checklist. The statements, as observed in movement situations using the diagnostic criteria of the diagnostic systems mentioned above, were defined and assessed by the expert team, thus ensuring the validity of all statements. Seeking to check the validity of the construct (checklist) of expression of children's internal problems in motor behavior, two assumptions were made: 1) the sum of the values of the subscales of internal problems of the Teacher's Report Form (6-18 years) and 11-18-year-old Youth Self Report Form should moderately correlate with the sum of values of the checklist of observation of motor functions, and 2) the sum of children's values in the subscales of external problems of the Teacher's Report Form (6-18 years) and 11-18-year-old Youth Self Report Form should not be related to the sum of values of the observation checklist.

Having checked the first assumption, we received that the data of the observation checklist moderately correlated with the data of the subscales of internal problems; a stronger relation was with the data of the subscales of internal problems of reports filled in by children (see Table 2). Having checked the second assumption that the sum of children's values in the subscales of external problems of the Teacher's Report Form (6-18 years) and 11-18-yearold Youth Self Report Form should not be related to the sum of values of the observation checklist, it was found that the sum of values of the observation checklist weakly correlated with the values of the 


\begin{tabular}{|l|c|c|c|}
\hline & $\mathbf{N}$ & $\begin{array}{c}\text { Correlation } \\
\text { coeficient }\end{array}$ & $\mathbf{p}$ \\
\hline $\begin{array}{l}\text { Observation protocol and subcale of internal } \\
\text { problems (filled in by teachers) }\end{array}$ & 75 & $0.42^{* *}$ & 0.000 \\
\hline $\begin{array}{l}\text { Observation protocol and subcale of internal } \\
\text { problems (filled in by children) }\end{array}$ & 75 & $0.46^{* *}$ & 0.000 \\
\hline $\begin{array}{l}\text { Observation protocol and subcale of external } \\
\text { problems (filled in by teachers) }\end{array}$ & 75 & $0.26^{*}$ & 0.022 \\
\hline $\begin{array}{l}\text { Observation protocol and subcale of external } \\
\text { problems (filled in by children) }\end{array}$ & 75 & $0.37^{* *}$ & 0.001 \\
\hline
\end{tabular}

Table 2. Correlation between checlist and subcales of internal and external problems

subscale of external problems of teachers' external problems, but the relation between the observation checklist and values of the children's external problems subscale was acceptable (see Table 2).

\section{DISCUSSION}

Having composed a new assessment checklist it is important to explore, if this instrument may be used and if it may be expected that it provides the information that is expected to be received thus, it is important to analyze the reliability and validity of the new construct (Hinkle et al., 2003; Thomas, Nelson, 2005). More often it is emphasized that, when stating that one or another instrument is valid, research generalizations should be narrowed down to population and environment, for which the measuring instrument was created (Linacre, 2000; Ulrich, 2002). Due to the reasons mentioned above three separate methods (categories) to prove validity were used.

Validity content-related evidence reflects the degree to which the test tasks, questions or a checklist's statements reflect a certain defined area or entity. Content validity is usually generalized by logical validity (Yaghmale, 2003). In order to ensure the validity of the new checklist's contents, the following actions should be taken: a) to define the area of interest; b) to select an expert team which could assess the instrument using the set criteria; c) to select suitable statements for the test. The validity of the contents of this new checklist was proved exactly in this sequence.

It should be noted that another method of choosing statements for a new checklist was also tried. F. C. Verhulst (2003) distinguishes a top-down approach and a bottom-up approach for choosing statements for a new assessment instrument. According to this distribution, the topdown approach was chosen to create this checklist. It means that a group of experts decided, which statements described motor behaviour of children with internal problems using diagnostic systems, and they suggested these statements for the future report. Another bottom-up approach of choosing statements is based on empiricism, i. e. a group of people observe children with internal problems and create a list of their typical motor behaviour which is later analyzed with the help of the factor analysis method. F. C. Verhulst (2003) and T. M. Achenbach (1991) state that such sequence of checklist construction allows to break free from the imperfection of diagnostic systems and to take a new look at emotional and behavioural disorders. The bottom-up approach of choosing statements was not chosen because for this approach a bigger amount of more exhaustive research is needed for confirmation of validity of the suggested checklist.

Seeking to retain the validity of the checklist's content and to provide it with empiricism, the advice of J. Yun and D. A. Ulrich (2002) was used. Experts of different specialities were chosen for the assessment and correction of statements. The criteria of expert selection may seem not strict enough, but the future instrument is not meant for diagnosis, and conclusions, received with its help, will not have serious outcomes for a child's development. Since the future checklist is intended for observation of motor behaviour, the most important criteria for selection of experts was the ability to observe motor behaviour. The experts were asked to attribute a degree to each statement, by which it is observed in a movement situation. Since an assumption was made that diagnostic criteria described behaviour of children with internal problems per se, there was a request to disassociate from the assessment of contents of the statement. The decision which statement should be left in the final version was quite difficult because the general internal consistency of the scale of 68 statements was high (Cronbach's $\alpha=0.929$ ), and that means that the experts agreed that most of the statements were observed in a movement situation. But in this case it should be emphasized that this 
index is influenced by the length of the scale. The longer the scale, the bigger its internal consistency (Portney, Watkins, 2000). Then other methods of statistical analysis were used in order to select statements, which would be easily observed in a movement situation and would not be repetitive. Therefore, averages of expert values were used to remove the statements which were assessed as not observed in a movement situation. All statements with an average of less than 3.75 were removed, and so the checklist became shorter. Then the discrimination index was calculated. A. Anastasi and S. Urbina (1997) state that the sufficient value of this index for certain tests is 0.2 , but statements with the correlation of 0.35 with other statements were left in this checklist, because the test was intended to measure a unified construct. Based on the recommendations of D. A. Ulrich (2002), the remaining statements were selected with the help of logical thinking. Going back to diagnostic criteria and discussion of the place of the analyzed statement in the checklist, there was an attempt for the future checklist to encompass all internal problems observed in a movement situation. B. Lowenthal's (2001) suggestions were used when forming the checklist, but of course there is a need for further development of the checklist form.

The compiled checklist was tested twice. Both times useful advice was received for further work with the checklist, and data were collected for further examination of validity and reliability. But only theoretical validity is not sufficient in order to claim that the new checklist is valid. Seeking for stronger proof, the construct identification validity of the new checklist was also assessed. Construct validity is the degree, by which the test measures the theoretical construct or feature (Anastasi, Urbina, 1997). In this case a question was raised if the checklist could in fact help identify expressions of children's internal problems in motor behaviour. The received results allow to state that the new checklist is valid for the observed sample of children; it may be used to assess the observed motor behaviour of children with internal problems. The value from 0.4 to 0.5 of the correlation coefficient may be interpreted as an average relation between the data received from the observation checklist and data of the subscales of internal problems. This is also confirmed by data presented in scientific literature when discussing low values of correlation coefficients, having in mind the information received from different informants. Literature states that there might be a weak connection $(r \approx 0.2-0.3)$ among answers of informants who observe children in different contexts, among answer results of parents and children, and among children themselves and among parents or teachers (Puura et al., 1998). That means that in this case the correlation $(r=0.46)$ among answers of children and observation results of the physical education teacher is sufficient. The correlation coefficient is stronger also because the physical education teacher who filled in the checklists did not know the children and had not communicated with them before.

A reliable instrument is such an instrument which acts with a predictable stability in fixed circumstances (Portney, Watkins, 2000). Internal consistency of homogeneity of the checklist is one of the most important characteristics that ensures reliability enabling to decide if all statements of the checklist are homogeneous, or if some of them are attributable to another area (Portney, Watkins, 2000). The internal consistency of the checklist's Cronbach's $\alpha$ increased from 0.79 to 0.83 after the removal of two statements from the checklist. Probably the statement "the child is "glued" to the teacher or another adult" should be removed from the checklist when the checklist is improved because, after giving it a lot of thought, it is really difficult to assess this statement on a 5-point scale according to the intensity of the manifestation of "being "glued" to someone". Before removing the statement "a child experiences fits of anger" research with a more heterogeneous population should be performed, including children with serious internal problems in the research.

Determination of the reliability index among separate assessors allows to state that results received by an assessor reflect the real result of the assessed, and results may be interpreted and applied with bigger confidence (Portney, Watkins, 2000). Reliability among separate observers was calculated using the intraclass correlation coefficient. A good accordance value was received ( $\mathrm{ICC}=0.81$ ). But as the checklist is developed, it is useful to discuss two questions: a) selection and interpretation of the intraclass correlation coefficient model. Basically the ICC index was selected due to its advantages over the simple correlation coefficient. L. G. Portney and M. P. Watkins (2000) distinguish two main advantages: 1 ) when a simple correlation is calculated, only two observers may be compared at once, whereas the ICC index allows to compare the compatibility of the opinion of many observers at once; 2) a simple correlation coefficient cannot distinguish the dispersion component from the data with no regard if the dispersion is because 
of an error factor or because of real differences in data. The ICC is one of the suitable indices, when a Likert type scale is used for assessment. Since it was planned beforehand that it was important to prove that other similar observers could receive similar results, the ICC calculation model was chosen, where each person was assessed by the same number of observers. It is expected that observers reflect a population of similar observers because there is an aim to generalize that students, who have got acquainted with children's motor development, could use this checklist. Although the sample of assessors is not accidental, nevertheless L. G. Portney and M. P. Watkins (2000) recommend choosing the ICC calculation model that was used because in another case it would be possible to state that results are reliable only for those observers who have performed the observation. A question may arise, why children were observed by students, and not a physical education teacher or a specialist of applied physical activity. Such selection was determined by two reasons: a) firstly, there is the problem of research organisation: it would be quite hard to collect a sufficiently big group of physical education teachers, and it would be even more difficult to collect a group of specialists of applied physical activity; b) secondly, an assumption was raised that if reliable results were received among students who had little practice of work with children with special needs, this would ensure the results among specialists with bigger experience to be also reliable. Of course, the latter assumption should be tested. Other indicators that ensure reliability of a checklist could also be calculated (for example, the index of repeated testing, stability in time). Besides, specificity and sensitivity of the checklist should be analysed also, identifying which value defines that a child needs help of qualified specialists.

\section{CONCLUSIONS AND PERSPECTIVES}

Using diagnostic systems DSM-IV and ICD-10, a list of 68 statements was composed that codes the expression of internal problems in motor behaviour. Having performed statistical and empirical analysis of all statements, a checklist of 14 statements for observation of the expression of internal problems in motor behaviour was composed.

Observation data about motor behaviour of 11-12-year-old children was gathered, using the composed checklist. The data showed that the researched children did not have internal problems. Statements that might describe motor behaviour of children with internal problems better than other statements were distinguished.

Based on Cronbach's $\alpha(\alpha=0.79)$, a satisfactory internal consistency of the checklist was determined. After the removal of two statements from the checklist, the internal consistency increased to good $(\alpha=0.83)$. Research with a clinical sample would allow to conclude about the heterogeneity of the statements mentioned above more strongly. A good concurrence level among different observers was identified with the help of the intraclass correlation coefficient $(\mathrm{ICC}=0.81$ ).

Having assessed the validity of the checklist's content, statements, and the construct, it was determined that the checklist was valid for the determination of expressions of internal problems in motor behaviour for the sample of the observed children.

\section{REFERENCES}

Achenbach, T. M. (1991). Integrative guide for the 1991 CBCL/4-18, YRS and TRF profiles. Burlington, VT: University of Vermont, Department of Psychiatry.

Anastasi, A., Urbina, S. (1997). Psychological Testing. Upper Saddle River, NJ: Prentice-Hall.

Causgrove Dunn, J., Dunn, J. (2006). Psychosocial determinants of physical education behavior in children with movement difficulties. Adapted Physical Activity Quarterly, 23, 293-309.

Cone, J. D. (1978). Truth and Sensitivity in Behavioral Assessment. Paper Presented at the Meeting of the Association for the Advancement of Behavioral Therapy. Chicago.
Diagnostic and Statistical Manual of Mental Disorders. (1994). $4^{\text {th }}$ edition (DSM-IV). Washington: American Psychiatric Association.

Fortes, M., Ninot, G., Delignieres, D. (2005). The Auto-regressive integrated moving average procedures: Implications for adapted physical research. Adapted Physical Activity Quarterly, 22, 221-236.

Hinkle, D. E., Wiersma, W., Jurs, S. G. (2003). Applied Statistics for the Behavioral Sciences. Boston: Houghton Mifflin Company.

Linacre, J. M. (2000). New approaches to determining reliability and validity. Research Quarterly for Exercise and Sport, 71. 129-136. 
Lowenthal, B. (2001). Abuse and Neglect: The Educator's Guide to the Identification and Prevention of Child Maltreatment. Baltimore: Paul H. Brookes.

Mol Lous, A., Wit, C. A., De Bruyn, E. J., RiksenWalrawen, J. M. (2002). Depression markers in young children's play: A comparison between depressed and non-depressed 3 to 6 years old in various play situations. Journal of Child Psychology and Psychiatry, 43 (8), 1029-1038.

Pool, J. L., Hourcade J. (2011). Developmental screening: A review of contemporary practice. Education and Training in Autism and Developmental Disabilities, 46 (2), 267-275.

Portney, L. G., Watkins, M. P. (2000). Foundations of Clinical Research: Applications to Practice ( $2^{\text {nd }}$ ed.). Norwalk, CT: Appleton \& Lange.

Puura, K., Almgvist, F., Tammen, T. et al. (1998). Children with symptoms of depression - what do adults see? Journal of Child Psychology and Psychiatry, 39 (4), 577-585.

Saleem, S., Mehmood, Z. (2011). Development of a scale for assessing emotional and behavioral problems of school children. Pakistan Journal of Social and Clinic Psychology, 9, 73-78.

Seligman, L. D., Ollendick, T. H. (1998). Comorbidity of anxiety and depression in children and adolescents:
An integrative review. Clinical Child and Family Psychology Review, 1 (2), 125-143.

Thomas, J. R., Nelson, J. K. (2005). Research Methods in Physical activity. Human Kinetics.

Ulrich, D. A. (2002). Test of Gross Motor Development. Austin, TX; PRO-ED.

World Health Organization. (1993). The ICD-10 Classification of Mental and Behavioral Disorders: Diagnostic Criteria for Research. Geneva: World Health Organization.

Yaghmale, F. (2003). Content validity and its estimation. Journal of Medical Education, 3 (1), 25-27.

Yun, J., Ulrich, D. A. (2002). Estimating measurement validity: A tutorial. Adapted Physical Activity Quarterly, 19, 32-47.

Verhulst, F. C. (2003). Child and Adolescent Epidemiology. Paper present at the Nordic/Baltic International workshop on Positive Psychology and Research Methodology, Law University of Lithuania: Vilnius, Lithuania.

Žukauskienè, R., Ignatavičienè, K., Daukantaitė, I. (2003). Subscales scores of the Lithuanian version of CBCL: Preliminary data on the emotional and behavioral problems in childhood and adolescence. European Child \& Adolescent Psychiatry, 12 (3), 136-143.

\title{
MOTORINIO ELGESIO PROTOKOLO MODELIAVIMAS
}

\author{
Jūratė Požèrienė, Diana Rèklaitienė, Danguolė Venslavičè \\ Lietuvos kūno kultūros akademija, Kaunas Lietuva
}

\section{SANTRAUKA}

Tyrimo pagrindimas ir hipotezè. Tyrimas pradètas remiantis hipoteze, kad tiesioginis vaiko stebejjimas gali būti vidinių problemų vertinimo dalis. Vaikų, sergančių depresija, tyrimų rezultatai rodo ryškius elgesio depresijos simptomus, pavyzdžiui, standartizuotų procedūrų metu galima stebẻti psichomotorinį sujaudinimą.

Tikslas - sukurti motorinio elgesio stebëjimo protokolą koduojant specifinį vaikų, turinčių vidinių sutrikimų, elgesi.

Metodai. Buvo tiriami 11-12 metų vaikai ( $\mathrm{n}=75$ ), kurių dalyvavimas kūno kultūros pamokoje buvo nufilmuotas. Motorinio elgesio kodavimui naudoti teiginiai iš DSM-IV ir ICD- 10. Sudaryto protokolo informatyvumui patikrinti buvo naudojami Mokytojo vertinimo klausimynas ir 11-18 metu Jaunuolio savęs vertinimo lapas (TRF). Protokolo patikimumas taip pat buvo patikrintas.

Rezultatai. Iš 68 teiginių, nusakančių vaikų motorini elgesị, buvo atrinkta 14 ir sudarytas protokolas, nusakantis vaikų, turinčiu vidiniu problemu, motorini elgesi. Tyrimo rezultatai parodé, kad sudaryto protokolo vidinis suderinamumas (Cronbach $\alpha=0,79)$ ir patikimumas $(I C C=0,81)$ yra geras. Nereikšmingas stebetojų dispersijos rezultatas $(\mathrm{F}=7,233,(\mathrm{df}=4) \mathrm{p}=0,423)$ rodo, kad jie, vertindami vaikus, sutarè.

Aptarimas ir išvados. Stebètų vaikų imties rezultatų protokolas yra informatyvus ir naudingas nustatant potencialias vaikų vidines problemas bei padedant planuoti intervencijas, lemiančias motorini vaikų elgesi. Tyrimas turejjo keletą apribojimų - mažas tiriamujų skaičius, reikalinga išsamesnè protokolo informatyvumo bei patikimumo analizè.

Raktažodžiai: stebèjimas, vidinès problemos, motorinio elgesio protokolas, patikimumas, informatyvumas.

Gauta 2012 m. spalio 29 d.

Received on October 29, 2012

Priimta 2012 m. gruodžio 5 d.

Accepted on December 5, 2012
Corresponding author Jūratė Požèrienė

Lithuanian Academy of Physical Education

Sporto str. 6, LT-44221 Kaunas

Lithuania

E-mail j.pozeriene@lkka.lt 